\title{
Lessen uit 2020
}

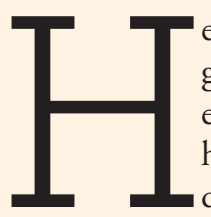

et jaar 2020 zal de geschiedenis ingaan als een bizar jaar. En voor het zorgpersoneel geldt dat misschien nog wel het meest. In dit nummer laten we 5 verpleegkundigen aan het woord die het jaar 2020 niet snel zullen vergeten. Verpleegkundige in de wijk Idsert bijvoorbeeld, die zelf corona kreeg, waarvan hij maanden later nog steeds herstellende is. En Ellen, die ineens bv'er (Bekende Verpleegkundige) werd doordat ze in het tv-programma Frontberichten vertelde over haar werk op een covid-afdeling. Hoewel eerst wat onwennig, zou ze dat optreden voor tv 'zo weer doen.'

Wie dat vaker doet en inmiddels een doorgewinterde bv'er is, is Tommie Niessen. Onlangs verscheen zijn tweede boek: Tommie in gesprek. Wat kunnen we leren van zijn ervaringen? 'Als ik uitgenodigd word voor een televisieprogramma denk ik eerst: is het nuttig? Maar als van mij verwacht wordt dat ik ga klagen, dan kies ik daar niet meer voor.' Een mooie tip denk ik, die ook goed past bij de nieuwe glansrol die verpleegkundigen hebben gekregen in deze coronacrisis. Het dwingt je na te denken over hoe je jezelf (en daarmee de beroepsgroep) naar buiten toe presenteert. Maar ook op inhoudelijk vlak stipt Tommie een belangrijk punt aan: 'het maakt je als zorgverlener gelukkig als je ruimte pakt, ondanks bestaande structuren.' Dit gaat wat mij betreft ook over creativiteit en out of the box denken en zelfs over leiderschap.

Waar het eerder misschien lastiger was om de dagelijkse gang van zaken op je werk te veranderen of te innoveren, is deze coronatijd bijvoorbeeld een vliegwiel gebleken voor digitale toepassingen in de zorg. 'De invloed van covid-19 op het gebruik van e-health - zoals beeldbellen, telebegeleiding, het gebruik van apps en brillen als Google glass - is groot', constateert Marian Adriaansen, lector innovatie in de care aan de HAN (Hogeschool Arnhem Nijmegen). 'Er zijn veel digitale initiatieven uitgebouwd of opgestart. Voor corona verliep de digitalisering nogal moeizaam. We zijn benieuwd of er bij zorgverleners en clienten een knop is omgezet.'

We zullen het gaan zien in 2021. Het zal een jaar worden waarin de discussies over het covid-19-vaccin ongetwijfeld flink zullen oplaaien, de coronabonussen worden uitgekeerd (of niet) en nieuwe cao-onderhandelingen opnieuw op de agenda staan. Nursing zal er weer bovenop zitten. De ongemakken die covid ons nog altijd dagelijks geeft, zullen we nog wel een tijdje blijven merken, maar we houden vol. De lessen van dit jaar nemen we in ieder geval mee voor 2021. Fijne feestdagen en alvast een heel gelukkig - en vooral gezond - nieuwjaar.

Wij vinden dat je ook bijzonder trots mag zijn op jezélf in dit bijzondere jaar. Wij zijn dat in ieder geval wel. Vandaar in dit nummer een klein cadeautje. Voor jezelf of voor die ene collega.

\section{Alexia Hageman}

\section{Hoofdredacteur Nursing}

Alexia.Hageman@bsl.nl

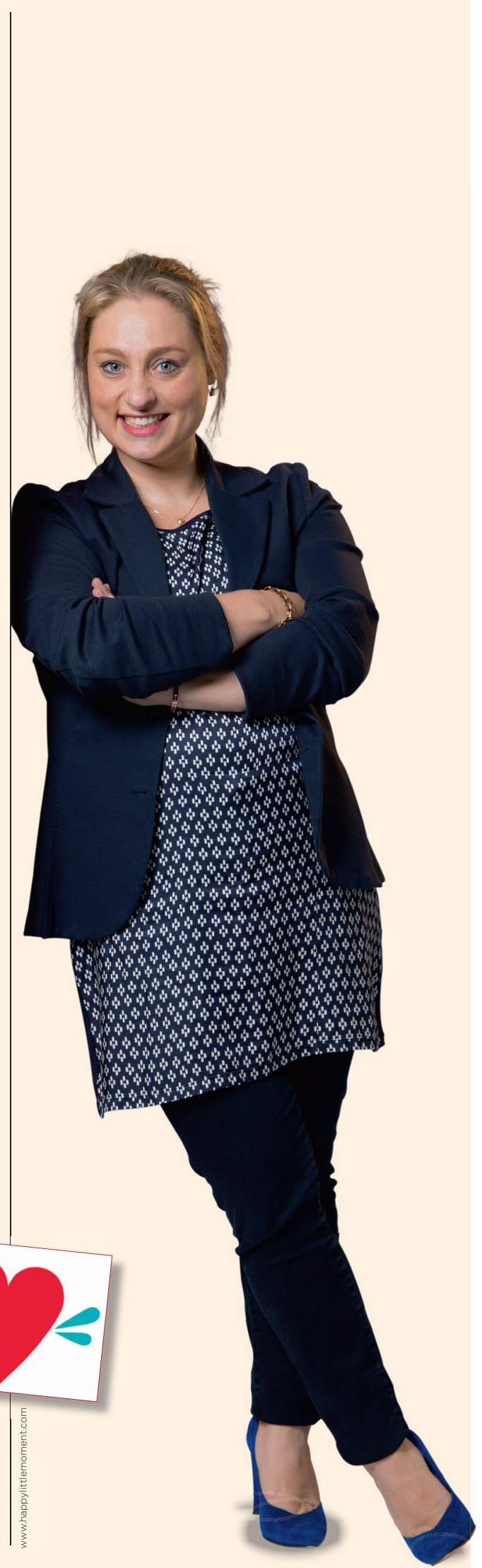

